\title{
Use of Virtual Reality for the Management of Anxiety and Pain in Dental Treatments: Systematic Review and Meta-Analysis
}

\author{
Nansi López-Valverde ${ }^{1}{ }^{\circledR}$, Jorge Muriel Fernández ${ }^{1}$, Antonio López-Valverde ${ }^{1, *(0)}$, \\ Luis F. Valero Juan ${ }^{2}$, Juan Manuel Ramírez ${ }^{3}$, Javier Flores Fraile ${ }^{1} \mathbb{C}$, Julio Herrero Payo ${ }^{1}$, \\ Leticia A. Blanco Antona ${ }^{1}$, Bruno Macedo de Sousa ${ }^{4}(\mathbb{D})$ and Manuel Bravo ${ }^{5}$ \\ 1 Department of Surgery, University of Salamanca, Instituto de Investigación Biomédica de \\ Salamanca (IBSAL), 37007 Salamanca, Spain; nlovalher@usal.es (N.L.-V.); murimuriel@gmail.com (J.M.F.); \\ j.flores@usal.es (J.F.F.); jhpayo@usal.es (J.H.P.); lesablantona@gmail.com (L.A.B.A.) \\ 2 Department of Biomedical and Diagnostic Sciences, University of Salamanca, Ayda. Alfonso X El Sabio S/N, \\ 37007 Salamanca, Spain; luva@usal.es \\ 3 Department of Morphological Sciences, University of Cordoba, Avenida Menéndez Pidal s/n, \\ 14071 Cordoba, Spain; jmramirez@uco.es \\ 4 Institute for Occlusion and Orofacial Pain Faculty of Medicine, University of Coimbra, Polo I - Edifício \\ Central Rua Larga, 3004-504 Coimbra, Portugal; brunomsousa@usat.es \\ 5 Department of Preventive and Community Dentistry, Facultad de Odontología, Campus de Cartuja s/n, \\ 18071 Granada, Spain; mbravo@ugr.es \\ * Correspondence: anlopezvalverde@gmail.com \\ Received: 26 February 2020; Accepted: 27 March 2020; Published: 5 April 2020

Abstract: Background: Dental treatments often cause pain and anxiety in patients. Virtual reality (VR) is a novel procedure that can provide distraction during dental procedures or prepare patients to receive such type of treatments. This meta-analysis is the first to gather evidence on the effectiveness of VR on the reduction of pain (P) and dental anxíety (DA) in patients undergoing dental treatment, regardless of age. Methods: MEDLINE, CENTRAL, PubMed, EMBASE, Wiley Library and Web of Science were searched for seientific articles in November 2019. The keywords used were: "virtual reality", "distraction systems", "dental anxiety" and "pain". Studies where VR was used for children and adults as a measure against anxiety and pain during dental treatments were included. VR was defined as a three-dimensional environment that provides patients with a sense of immersion, transporting them to appealing and interactive settings. Anxiety and pain results were assessed during dentâ treatments where VR was used, and in standard care situations. Results: 31 studies were identified, of which 14 met the inclusion criteria. Pain levels were evaluated in four studies $(n=4)$, anxiety levels in three $(n=3)$ and anxiety and pain together in seven $(n=7)$. Our meta-analysis was based on ten studies $(n=10)$. The effect of VR was studied mainly in the pediatric population (for pain SMD = -0.82). In the adult population, only two studies (not significant) were considered. Conclusions: The findings of the meta-analysis show that VR is an effective distraction method to reduce pain and anxiety in patients undergoing a variety of dental treatments; however, further research on VR as a tool to prepare patients for dental treatment is required because of the scarcity of studies in this area.

Keywords: virtual reality; distraction systems; dental anxiety; pain

\section{Introduction}

Pain suppression during dental interventions has been a major accomplishment for humankind. In 1842, William E. Clarke gave ether to a patient for the removal of a tooth; later, in 1844, a dentist 
named Horace Wells used nitrous oxide as an anesthetic for dental extractions; and in 1846, another dentist, William T. G. Morton, became a pioneer in the use of inhaled ether as an anaesthetic at the Massachusetts General Hospital [1].

Patient anxiety when facing dental procedures is determined by two circumstances: on the one hand, the prior act of anesthetizing, which in itself frequently causes a state of phobia [2] and, on the other hand, the subsequent dental treatment. The number of studies on this pathology has exponentially increased over the last few years, growing from a very low number in the 1940s to the more than 6000 papers that are currently available, according to the U.S. National Library of Medicine (Figure 1).

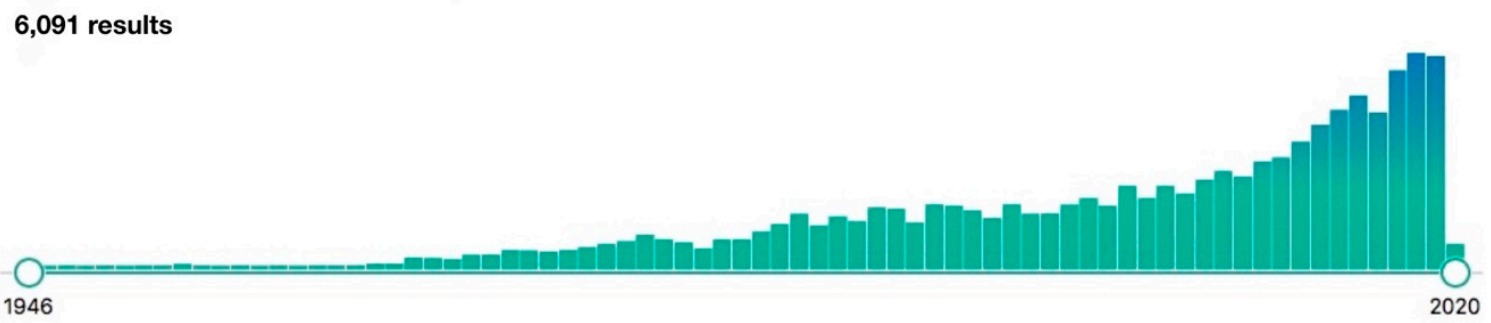

Figure 1. Increasing tendency of publications, according the U.S. National Library of Medicine database, using "dental phobia" as the keyword.

Different therapies have been proposed for the prevention and treatment of P and DA, among them virtual reality (VR) distraction techniques [3].

Although it is a concept that is difficult to define, VR is generally accepted as a three-dimensional environment generated by means of computer technology that creates a sense of immersion in the user, transporting the individual to appealing and interactive settings [4].

The benefits of using VR for the reduction of dental anxiety (DA) and pain (P) levels during dental procedures has been extensively addressed in scientific literature [5-9], and its usefulness as a distraction tool is receiving increasing attention in medical contexts [9]. During aversive experiences, VR can improve pain management [10] and reduce the perceived duration of the procedure [11]. Moreover, a recent systematic review examined the effectiveness of virtual reality distraction in reducing pain [12]. This could be an advantage for many patients who reject DA control using anti-anxiety drugs because of their disadvantages or side effects, which can be, among others, impaired cognitive function and coordination, since they act as depressants on specific areas of the central nervous system [13-15].

The purpose of this study was to conduct a systematic review of literature comparing the effectiveness of the use of VR as a method for reducing anxiety and pain levels during dental treatment. This systematic review constitutes an essential tool to synthesize the scientific information available, increasing the validity of the conclusions and of individual studies, and identifying areas of uncertainty, where research is necessary. Meta-analysis (when possible) provides very useful information, to facilitate understanding of the effect of a treatment or intervention, both in general and in specific groups of patients. In addition, it allows us to increase the precision in the estimation of the effect, detecting effects of moderate magnitude, but of clinical importance, that could go unnoticed in primary studies.

\section{Methods}

The study selection process was carried out according to the Preferred Reporting Items for Systematic Review and Meta-Analyses (PRISMA) guidelines for systematic reviews and meta-analysis [16].

\subsection{Protocol}

The search strategy was conducted using the population, intervention, comparison and outcome (PICO) framework, based on the following question: 
"Are distraction techniques using VR effective against the anxiety and pain caused by dental procedures?"

To answer this question, a population of patients undergoing dental treatment, with no age limit, were selected. The intervention consisted in using audio-visual or VR distraction methods. Controls were patients who were not subjected to audio-visual or VR distraction methods. The results revised in the literature were the DA or P values obtained using different validated scales:

- $\quad$ For pain: Visual Analogic Scale (VAS), Wong-Baker Faces Scale (W-BFS) and Faces Pain Scale-Revise (FPS-R).

- $\quad$ For anxiety: Consolability Scale (FLACC), Verbal Rating Scale (VRS), Modified Dental Anxiety Scale (MDAS), (Norman Corah's anxiety questionnaire (NCAQ) and Venham's Clinical Anxiety Rating Scale (VCARS).

\subsection{Search Method for the Identification of Studies}

A search of the MEDLINE, CENTRAL, PubMed, EMBASE, Wiley Library and Web of Science electronic databases was conducted in November 2019 to identify relevant scientific articles. The search terms used were: "virtual reality", "distraction systems", "dental anxiety", "pain"

\subsection{Inclusion and Exclusion Criteria}

Inclusion criteria:

(a) Articles published in English.

(b) Randomized controlled clinical trials related to dental anxiety and pain associated with dental procedures in children and adults.

(c) Studies assessing anxiety in said procedures.

Exclusion criteria:

(a) Non-randomized studies or non-controlled clinical trials.

(b) Comparative studies.

(c) Narrative reviews and systematic reviews.

(d) Case studies.

(e) Irrelevant and duplicate studies and those that did not meet the established inclusion criteria.

\subsection{Data Extraction and Analysis}

Studies that made no reference to the research question were removed, and the titles and abstracts of the articles selected were obtained and entered in an Excel spreadsheet. Two reviewers (NL-V and JMF) selected the titles and abstracts independently. Discrepancies in terms of study inclusion were discussed between the two mentioned reviewers until consensus was reached. Subsequently, the full texts of the selected studies were obtained for their review and inclusion.

\subsection{Risk of Bias (RoB) of Included Articles}

The Cochrane Collaboration, London, UK, tool was used to assess the methodology of the scientific evidence in all the selected studies [17].

\subsection{Quality of the Reports of the Included Studies}

This was assessed according to the modified Strengthening the Reporting of Observational studies in Epidemiology (STROBE) statement [18], which includes a total of 22 items. Each item was assessed by reviewers NL-V and JMF, who attributed scores of 0 (not reported) or 1 (reported), carrying out a complete count of all the studies included (Table 1). 
Table 1. Checklist of Reporting of Observational studies in Epidemiology (STROBE) criteria reported by the included studies. Each item was judged as "0" (not reported) or "1" (reported). The total score of each of included studies was also recorded.

\begin{tabular}{|c|c|c|c|c|c|c|c|c|c|c|c|c|c|c|}
\hline Authors & $\begin{array}{c}\text { Asl } \\
\text { Aminabadi } \\
\text { et al. [22] }\end{array}$ & $\begin{array}{l}\text { Tanja-Dijkstra } \\
\text { et al. [9] }\end{array}$ & $\begin{array}{c}\text { Nunna } \\
\text { et al. } \\
\text { [23] }\end{array}$ & $\begin{array}{l}\text { Gujjar } \\
\text { et al. [6] }\end{array}$ & $\begin{array}{l}\text { Niharika } \\
\text { et al. [24] }\end{array}$ & $\begin{array}{l}\text { Al-Halabi } \\
\text { et al. [20] }\end{array}$ & $\begin{array}{l}\text { Raghav } \\
\text { et al. [7] }\end{array}$ & $\begin{array}{l}\text { Tanja-Dijkstra } \\
\text { et al. [19] }\end{array}$ & $\begin{array}{l}\text { Shetty } \\
\text { et al. } \\
\text { [25] }\end{array}$ & $\begin{array}{l}\text { Al-Khotani } \\
\text { et al. [26] }\end{array}$ & $\begin{array}{l}\text { Mitrakul } \\
\text { et al. } \\
\text { [27] }\end{array}$ & $\begin{array}{l}\text { Asvanund } \\
\text { et al. [28] }\end{array}$ & $\begin{array}{c}\text { Bentsen } \\
\text { et al. } \\
\text { [21] }\end{array}$ & $\begin{array}{l}\text { Sweta } \\
\text { et al. [2] }\end{array}$ \\
\hline \multicolumn{15}{|l|}{ Section and item } \\
\hline 1. Title and Abstract & 1 & 1 & 1 & 1 & 1 & 1 & 1 & 1 & 1 & 1 & 1 & 1 & 1 & 1 \\
\hline \multirow{2}{*}{\multicolumn{15}{|c|}{ Introduction }} \\
\hline & & & & & & 1 & 1 & 1 & 1 & 1 & 1 & 1 & 1 & 1 \\
\hline 3. Objectives & 1 & 1 & 1 & 1 & 1 & 1 & 1 & 1 & 1 & 1 & 1 & 1 & 1 & 1 \\
\hline \multirow{2}{*}{\multicolumn{15}{|c|}{ Methods }} \\
\hline 4. Study design & & & & & & & 1 & 1 & 1 & 1 & 1 & 1 & 1 & 1 \\
\hline 5. Setting & 1 & 1 & 1 & 1 & 1 & 1 & 1 & 0 & 1 & 1 & 1 & 1 & 1 & 1 \\
\hline 6. Participants & 1 & 1 & 1 & 1 & 1 & 1 & 1 & 1 & 1 & 1 & 1 & 1 & 1 & 1 \\
\hline 7. Variables & 1 & 1 & 1 & 1 & 1 & 1 & 1 & 1 & 1 & 1 & 1 & 1 & 1 & 1 \\
\hline 8. Data sources/ & 1 & 1 & 1 & 1 & 1 & 1 & 1 & 1 & 1 & 1 & 1 & 1 & 1 & 1 \\
\hline $\begin{array}{l}\text { Measurement } \\
\text { 9. Bias }\end{array}$ & 1 & 0 & 0 & 0 & 0 & 1 & 0 & 0 & 0 & 1 & 1 & 0 & 1 & 0 \\
\hline 10. Study Size & 1 & 1 & 1 & 1 & 1 & & 1 & 1 & 1 & 1 & 1 & 1 & 1 & 1 \\
\hline 11.Quantitative variables & 1 & 1 & 1 & 1 & 1 & & 1 & 1 & 1 & 1 & 1 & 1 & 1 & 1 \\
\hline 12. Statistical Methods & 1 & 1 & 1 & 1 & 1 & & 1 & 1 & 1 & 1 & 1 & 1 & 1 & 1 \\
\hline \multicolumn{15}{|l|}{ Results } \\
\hline 13. Participants & 1 & 1 & 1 & 1 & & & 1 & 1 & 1 & 1 & 1 & 1 & 1 & 1 \\
\hline 14. Descriptive data & 1 & 1 & 1 & 1 & & & 1 & 1 & 1 & 1 & 1 & 1 & 1 & 1 \\
\hline 15. Outcome data & 1 & 1 & 1 & 1 & & & 1 & 1 & 1 & 1 & 1 & 1 & 1 & 1 \\
\hline 16. Main results & 1 & 1 & 1 & 1 & & & 1 & 1 & 1 & 1 & 1 & 1 & 1 & 1 \\
\hline 17. Other analyses & 0 & 0 & 1 & 1 & 1 & & 1 & 0 & 1 & 0 & 1 & 1 & 0 & 1 \\
\hline \multicolumn{15}{|l|}{ Discussion } \\
\hline 18. Key results & 1 & 1 & 1 & & & 1 & 1 & 1 & 1 & 1 & 1 & 1 & 1 & 1 \\
\hline 19. Limitations & 1 & 0 & 0 & 0 & 0 & 1 & 0 & 0 & 0 & 1 & 1 & 0 & 1 & 0 \\
\hline 20. Interpretation & 1 & 1 & 1 & 1 & 1 & 1 & 1 & 1 & 1 & 1 & 1 & 1 & 1 & 1 \\
\hline 21. Generalisability & 1 & 1 & 1 & 1 & 1 & 1 & 1 & 1 & 1 & 1 & 1 & 1 & 1 & 1 \\
\hline \multicolumn{15}{|l|}{ Other information } \\
\hline 22. Funding & 1 & 1 & & & 1 & 1 & 1 & 1 & 1 & 1 & 1 & 1 & 1 & 1 \\
\hline \multirow[t]{2}{*}{ Total score } & 21 & 19 & & 20 & 20 & 22 & 20 & 18 & 20 & 21 & 22 & 20 & 21 & 20 \\
\hline & \multicolumn{14}{|c|}{ Mode Value: $27.4( \pm 0.85)$} \\
\hline
\end{tabular}




\subsection{Statistical Analysis}

In the meta-analysis, four studies were excluded on the grounds that two of them [7,19] did not present results and the other two $[20,21]$ presented confusing results at the time of their assessment. Physiological data, such as pulse rate, degree of oxygen saturation, blood pressure and more were not included, incorporating data related to pain and anxiety only, during dental treatments. Pain and anxiety were analyzed separately in children and adults. The mean scores and SDs (standard deviations) for pain and anxiety, during the procedure with VR and control, were extracted from the selected articles, using mean scores and interquartile ranges, or reported, directly, by the authors of the studies. Other information not related to VR was not taken into consideration in our meta-analysis. The different measurement scales and VR devices used were not considered. The meta-analysis was performed using Stata v.14.2 (StataCorp LP, College Station, TX, USA) and closely followed the methods proposed by the Cochrane collaboration [17]. The methods can be observed in the different tables and figures. The standardized difference of means (SMD) was used as a measure of effect to account for different measurement scales both for anxiety and pain. Statistical heterogeneity among studies was assessed using the $Q$ test according to Dersimonian and Laird and the I2 index (heterogeneity: I2 $>30 \%$ being moderate, $>50 \%$ substantial and $>75 \%$ considerable [17]). We decided to pool the study-specific estimates with the random effects model to protect our composite estimates (for anxiety and pain) from heterogeneity in the context of a relatively limited number of studies. We also decided a priori to present the results not only for all the studies together, but also as a subgroup analysis according to age group (children and adults) derived from the different clinical usefulness and interpretation. Finally, funnel graphs (not shown) and p-value calculation (Egger test) were used to assess the publication bias.

\section{Results}

\subsection{Characteristics of the Studies}

Until November 2019, a total of 31 studies were gathered and subsequently assessed by the reviewers. Three duplicate studies were removed after an initial detection. A second detection led to the removal of 14 studies, which left a tofal of 14 full-text studies for the final selection $[2,6,7,9,19-28]$ (Figure 2). Pain levels were assessed in fourstudies, two in children [20,28] and two in adults [2,21]; anxiety levels in three, two in adults $[9,19]$ and one in children [26]; and anxiety and pain together in seven studies, five in children [22-25, 1 and two in adults [6,7].

Table 2 provides a general description of the details of each study. The risk of bias (RoB Cochrane Collaboration Tool) in the studies considered is shown in Figure 3. All the studies complied with random sequence. Two of the studies included $[25,28]$ did not comply with allocation concealment and only $35 \%$ complied with blinding of participants and personnel. It should be noted that none of the studies included complied with blinding of outcome assessment. 
Table 2. Details of each study.

\begin{tabular}{|c|c|c|c|c|c|c|c|c|}
\hline \multirow{2}{*}{$\begin{array}{l}\text { Study } \\
\text { (Year) }\end{array}$} & \multirow{2}{*}{ Journal } & \multirow{2}{*}{$\begin{array}{c}\text { Children } \\
\text { Values } \\
(\mathrm{Ma}, n, \mathrm{Ar})\end{array}$} & \multirow{2}{*}{$\begin{array}{c}\text { Adult Values } \\
\text { (Ma, } n, \text { Ar) }\end{array}$} & \multirow{2}{*}{ Dental Procedure } & \multirow{2}{*}{ VR Device Equipment } & \multicolumn{2}{|c|}{ Measuring Scales } & \multirow{2}{*}{ Outcomes } \\
\hline & & & & & & DA & $\mathbf{P}$ & \\
\hline $\begin{array}{l}\text { Asl Aminabadi } \\
\text { et al. } 2012[22]\end{array}$ & $\begin{array}{l}\text { J Dent Res Dent } \\
\text { Clin Dent } \\
\text { Prospect }\end{array}$ & $\begin{array}{c}\mathrm{Ma}=5.4 \\
n=120 \\
\mathrm{Ar}=4-6\end{array}$ & & $\begin{array}{l}\text { Restorative treatment in } \\
\text { primary molars. }\end{array}$ & $\begin{array}{l}\text { I-glasses 920HR Ilixco, Inc. Menlo } \\
\text { Park, CA, USA. }\end{array}$ & MDAS & W-BFS & $\begin{array}{l}\text { There was a significant decrease in pain perception and anxiety } \\
\text { scores with the use of VR eyeglasses during dental treatment. }\end{array}$ \\
\hline $\begin{array}{l}\text { Tanja-Dijkstra } \\
\text { et al } 2014 \text { [9] }\end{array}$ & Plos One J & & $\begin{aligned} \mathrm{Ma} & =33.1 \\
n & =69 \\
\mathrm{Ar} & =\mathrm{Nr}\end{aligned}$ & A simulated dental treatment. & $\begin{array}{l}\text { Eyeglasses EVuzix iWear VR920 } \\
\text { headset. Dual-core, 1.3GHz Intel } \\
\text { processor with Nvidia GT } \\
540 \text { M graphics card. }\end{array}$ & MDAS & & $\begin{array}{c}\text { Participants with higher } \\
\text { dental anxiety showed more interested in using VR during real } \\
\text { dental treatment than those with lower levels of dental anxiety. } \\
\text { Dental patients who have a positive dental treatment experience } \\
\text { thanks to VR, might have fewer unpleasant memories and thus } \\
\text { be less likely to postpone } \\
\text { a future dental visit. }\end{array}$ \\
\hline $\begin{array}{l}\text { Nunna et al } \\
2019[23]\end{array}$ & $\begin{array}{l}\text { J Dent Anesth } \\
\text { Pain Med }\end{array}$ & $\begin{array}{c}\mathrm{Ma}=\mathrm{Nr} \\
n=70 \\
\mathrm{Ar}=7-11\end{array}$ & & $\begin{array}{l}\text { - Counter-stimulation. } \\
\text { - Local anaesthesia } \\
\text { administration with virtual } \\
\text { reality distraction. }\end{array}$ & $\begin{array}{l}\text { Lenovo smartphone, Sennheiser } \\
\text { earphones, and ANTVR glasses. }\end{array}$ & VCARS & W-BFS & $\begin{array}{l}\text { Assessment of mean anxiety scores showed a significant } \\
\text { difference in girls belonging to the VR group. }\end{array}$ \\
\hline $\begin{array}{l}\text { Gujjar et al. } \\
2019[6]\end{array}$ & $\begin{array}{l}\text { Journal of } \\
\text { Anxiety } \\
\text { Disorders }\end{array}$ & & $\begin{array}{c}\mathrm{Ma}=\text { group } 1 \\
25.3 \\
\text { group } 2,23 \\
n=30 \\
\mathrm{Ar}=\mathrm{Nr}\end{array}$ & $\begin{array}{l}\text { Routine dental } \\
\text { treatment. }\end{array}$ & $\begin{array}{l}\text { Eyeglasses. Dell XPS-8700 desktop } \\
\text { with 4th Generation } \\
\text { Intel Core i下-4790 processor (8M } \\
\text { Caehe, up to } 4.0 \text { GHz) and ASUS } \\
\text { NVIDIA GEFORCE GT 750 TI OC } \\
\text { 2GB GDDR5 graphic card. }\end{array}$ & MDAS & VAS & $\begin{array}{l}\text { The results of this study provide evidence to support the efficacy } \\
\text { of } \\
\text { VR in the treatment of dental phobia. } \\
\text { Study limitations: } \\
\text { - No blinding of patients or therapist in the interventions. } \\
\text { - VR compared with pamphlet information. }\end{array}$ \\
\hline $\begin{array}{l}\text { Niharika et al. } \\
2018[24]\end{array}$ & $\begin{array}{l}\text { J Indian Soc } \\
\text { Pedod Prev } \\
\text { Dent }\end{array}$ & $\begin{array}{c}\text { Ma }=\text { Group A } \\
(7.17 \pm 0.316) \\
\text { Group B } \\
(7.28 \pm 0.300) \\
n=40 \\
\mathrm{Ar}=4-8\end{array}$ & & & $\begin{array}{l}\text { VR Box and Anti-Tank Virtual } \\
\text { Reality } 3 \text { D Glasses }\end{array}$ & MDAS & W-BFS & $\begin{array}{l}\text { Two groups. Childhood Anxiety-Related Disorders scores did } \\
\text { not differ significantly between the two groups. } \\
\text { In both groups, a statistically significant difference was detected } \\
\text { between the two treatment sessions (with and without VR). }\end{array}$ \\
\hline $\begin{array}{l}\text { Al-Halabi et al. } \\
2018[20]\end{array}$ & $\begin{array}{l}\text { Anaesth Pain \& } \\
\text { Intensive Care }\end{array}$ & $\begin{array}{c}\mathrm{Ma}=7.4 \\
n=102 \\
\mathrm{Ar}=7-10\end{array}$ & & $\begin{array}{l}\text { mandibular a } \\
\text { alveolar ne }\end{array}$ & 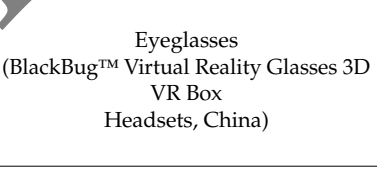 & & W-BFS & $\begin{array}{l}\text { Three groups. There was no significant difference in the anxiety } \\
\text { of groups. There was a statistically significant difference in the } \\
\text { anxiety and pain level in pulse rate. } \\
\text { Limitations: } \\
\text { - No blinding of the external investigator. } \\
\text { - The size of the VR Box was a little too big. }\end{array}$ \\
\hline $\begin{array}{l}\text { Raghav et al. } \\
\quad 2016[7]\end{array}$ & $\begin{array}{l}\text { BMC Oral } \\
\text { Health J }\end{array}$ & & & $\begin{array}{l}\text { torative dental procedure } \\
\text { ichmay or may not be } \\
\text { uning local anaesthesia. } \\
\text { Extraction procedure } \\
\text { iring local anaesthesia. }\end{array}$ & $\begin{array}{l}\text { Oculus development kit } 2 \mathrm{HMD} \text {, with } \\
\text { a resolution of } \\
960 \times 1080 \text { per eye and with a } \\
100 \text { degree field of view. }\end{array}$ & MDAS & VAS & $\begin{array}{c}\text { Two groups, VR (Idle, Mirror, Syringe, } \\
\text { Soundless Drill, Drill with Sound, } 35 \text { - second exposures) } \\
\text { and informational pamphlet control groups. } \\
\text { Efficacy of VR in the } \\
\text { treatment of dental phobia in the setting of the dental procedure. } \\
\text { A limitation of the } \\
\text { present study is the absence of in vivo exposure therapy as gold } \\
\text { standard } \\
\text { control group. }\end{array}$ \\
\hline
\end{tabular}


Table 2. Cont.

\begin{tabular}{|c|c|c|c|c|c|c|c|c|}
\hline \multirow{2}{*}{$\begin{array}{l}\text { Study } \\
\text { (Year) }\end{array}$} & \multirow{2}{*}{ Journal } & \multirow{2}{*}{$\begin{array}{l}\text { Children } \\
\text { Values } \\
\text { (Ma, } n, \text { Ar) }\end{array}$} & \multirow{2}{*}{$\begin{array}{l}\text { Adult Values } \\
\text { (Ma, n, Ar) }\end{array}$} & \multirow{2}{*}{ Dental Procedure } & \multirow{2}{*}{ VR Device Equipment } & \multicolumn{2}{|c|}{ Measuring Scales } & \multirow{2}{*}{ Outcomes } \\
\hline & & & & & & DA & $\mathbf{P}$ & \\
\hline $\begin{array}{l}\text { Tanja-Dijkstra } \\
\text { et al. } 2014 \text { [19] }\end{array}$ & Trials J & & $\begin{aligned} \mathrm{Ma} & =\mathrm{Nr} \\
n & =90 \\
\mathrm{Ar} & =\mathrm{Nr}\end{aligned}$ & Dental treatment & $\begin{array}{c}\text { Eyeglasses. } \\
\text { A Sony personal 3D viewer, connected } \\
\text { to an Alienware gaming laptop. } \\
\text { Participants can walk around in } \\
\text { the virtual environment by using a } \\
\text { Zeemote JS1 thumb } \\
\text { stick controller. }\end{array}$ & MDAS & & $\begin{array}{l}\text { This study compared two types of VR, natural environment and } \\
\text { urban environment. } \\
\text { It included both referred patients and inhouse patients from a } \\
\text { dental clinic and two separate procedures are described, one for } \\
\text { each type of patient. }\end{array}$ \\
\hline $\begin{array}{l}\text { Shetty et al. } \\
2019 \text { [25] }\end{array}$ & $\begin{array}{l}\text { The Journal of } \\
\text { Clinical } \\
\text { Paediatric } \\
\text { Dentistry }\end{array}$ & $\begin{array}{c}\mathrm{Ma}=\mathrm{Nr} \\
n=120 \\
\mathrm{Ar}=5-8\end{array}$ & & $\begin{array}{l}\text { Dental treatment } \\
\text { (vital pulp therapy) }\end{array}$ & $\begin{array}{l}\text { Eyeglasses. } \\
\text { VR device (i-glasses 920HR, Ilixco Inc., } \\
\text { Menlo Park, CA, USA) }\end{array}$ & MDAS & W-BFS & $\begin{array}{l}\text { Two groups. The group with VR distraction, reported a decrease } \\
\text { in the severity of anxiety. } \\
\text { Lower pain scores were observed in the VR group. }\end{array}$ \\
\hline $\begin{array}{l}\text { Al-Khotani et al. } \\
2016[26]\end{array}$ & $\begin{array}{l}\text { Acta } \\
\text { Odontologica } \\
\text { Scandinavica }\end{array}$ & $\begin{aligned} \mathrm{Ma} & =8.2 \\
n & =56 \\
\mathrm{Ar} & =7-9\end{aligned}$ & & $\begin{array}{l}\text { Dental examination, oral } \\
\text { hygiene information, } \\
\text { prophylaxis, restorative } \\
\text { treatment. }\end{array}$ & $\begin{array}{c}\text { Eyeglasses. } \\
\text { DVD Players, gaming systems like } \\
\text { Sony Play Station } \\
\text { Pro, Microsoft X-BOX, Nintendo WII } \\
\end{array}$ & MDAS & & $\begin{array}{l}\text { Two groups. VR and control group. Significant reduction in } \\
\text { anxiety throughout the restorative procedure (including } \\
\text { injection with local anaesthesia) in VR group. }\end{array}$ \\
\hline $\begin{array}{l}\text { Mitrakul et al. } \\
2015 \text { [27] }\end{array}$ & $\begin{array}{l}\text { European } \\
\text { Journal of } \\
\text { Paediatric } \\
\text { Dentistry } \\
\end{array}$ & $\begin{aligned} \mathrm{Ma} & =6.9 \pm 0.9 \\
n & =42 \\
\mathrm{Ar} & =5-8\end{aligned}$ & & $\begin{array}{l}\text { Restorative dental treatment in } \\
\text { maxilla or mandible under } \\
\text { local anaesthetic } \\
\text { Injection. }\end{array}$ & $\begin{array}{l}\text { Eyeglasses. (Shenzhen Longway } \\
\text { Vision Technology Co. Ltd, Shenzhen, } \\
\text { China). }\end{array}$ & FPS-R & FLACC & $\begin{array}{l}\text { Two groups. } \\
\text { Group } 1 \text { received treatment without wearing VR } \\
\text { in the first visit and wearing VR in a second visit. In Group 2, VR } \\
\text { was used vice versa. }\end{array}$ \\
\hline $\begin{array}{l}\text { Asvanund et al. } \\
2015[28]\end{array}$ & $\begin{array}{l}\text { Quintessence } \\
\text { International }\end{array}$ & $\begin{aligned} \mathrm{Ma} & =7 \pm 0.8 \\
n & =49 \\
\mathrm{Ar} & =5-8\end{aligned}$ & & & $\begin{array}{l}\text { (Shenzhen Longway Vision } \\
\text { Technology } \\
\text { td, Shenzhen, China). }\end{array}$ & FPS-R & FLACC & $\begin{array}{l}\text { Two groups. } \\
\text { The study assesses pain and anxiety without making a } \\
\text { distinction. } \\
\text { The limitation of this study is that the FLACC score was assessed } \\
\text { by playing back the video recording of each } \\
\text { visit, which was done by two paediatric dentists who could not } \\
\text { be blinded to the child's use of VR. }\end{array}$ \\
\hline $\begin{array}{l}\text { Bentsen et al. } \\
2001[21]\end{array}$ & $\begin{array}{l}\text { Eur J of Pain- } \\
\text { London }\end{array}$ & & $\begin{array}{c}\mathrm{Ma}=\mathrm{Nr} \\
n=23 \\
\mathrm{Ar}=20-49\end{array}$ & & $\begin{array}{c}\text { Video glasses } \\
\text { (NV-HD } 660 \text { PanasonicTM) }\end{array}$ & & VAS & $\begin{array}{l}\text { The study was a split-mouth, randomized design ( } 2 \text { dental } \\
\text { filling). Dental treatments were performed without anaesthesia. } \\
74 \% \text { of patients would prefer VR if they were to receive a second } \\
\text { dental filling. }\end{array}$ \\
\hline $\begin{array}{l}\text { Sweta et al. } 2019 \\
{[2]}\end{array}$ & $\begin{array}{l}\text { Ann Maxillofac } \\
\text { Surgery }\end{array}$ & & $\begin{array}{c}\mathrm{Ma}=39.72 \pm \\
15.93 \\
n=50 \\
\mathrm{Ar}=\mathrm{Nr}\end{array}$ & $\begin{array}{l}\text { Local anaesthesia in patients } \\
\text { undergoing a dental procedure. }\end{array}$ & $\mathrm{Nr}$ & NCAQ & & $\begin{array}{l}\text { Local anaesthesia and extractions reported the highest anxiety } \\
\text { levels among the patients. } \\
\text { Limitations of this study: } \\
\text { - Small sample size. } \\
\text { - Patients were not in control of their VR environment. }\end{array}$ \\
\hline \multicolumn{9}{|c|}{$\begin{array}{l}n \text { (Participant number); Ma (Mean age years); Ar (Age range years); Nr (Not reported); VAS (Visual Analogic Scale); W-BFS (Wong-Baker Faces Scale); FPS-R (Faces Pain Scale-Revised); } \\
\text { FLACC (Consolability Scale); VRS (Verbal Rating Scale); MDAS (Modified Dental Anxiety Scale); NCAQ (Norman Corah's anxiety questionnaire); VCARS (Venham's Clinical Anxiety } \\
\text { Rating Scale). DA (Dental Anxiety); P (Pain). }\end{array}$} \\
\hline
\end{tabular}




\section{FLOWCHART}

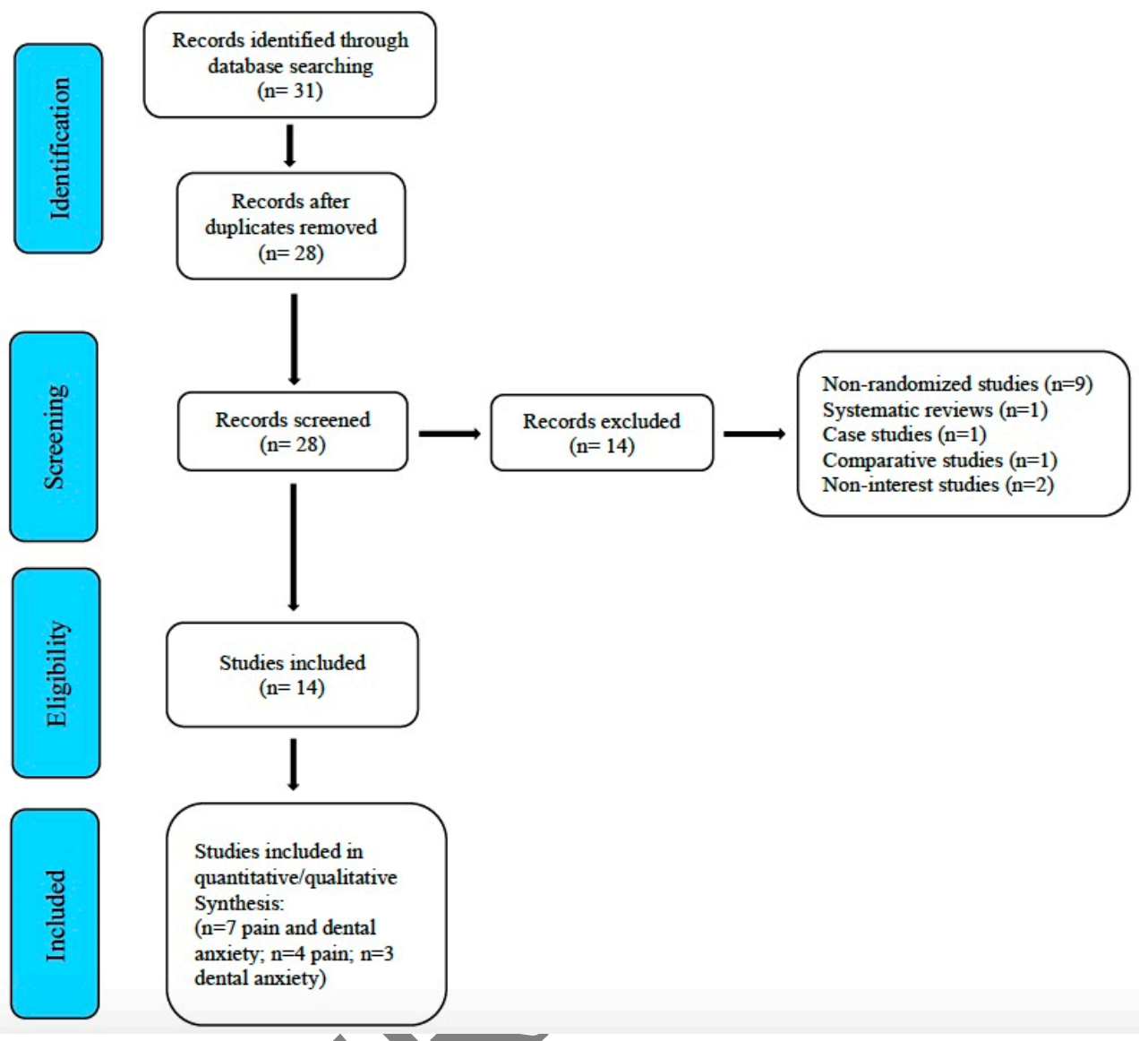

Figure 2. Flow chart of the study selection process. PRISMA (Preferred Reporting Items for Systematic Review and meta Analyses) [16]

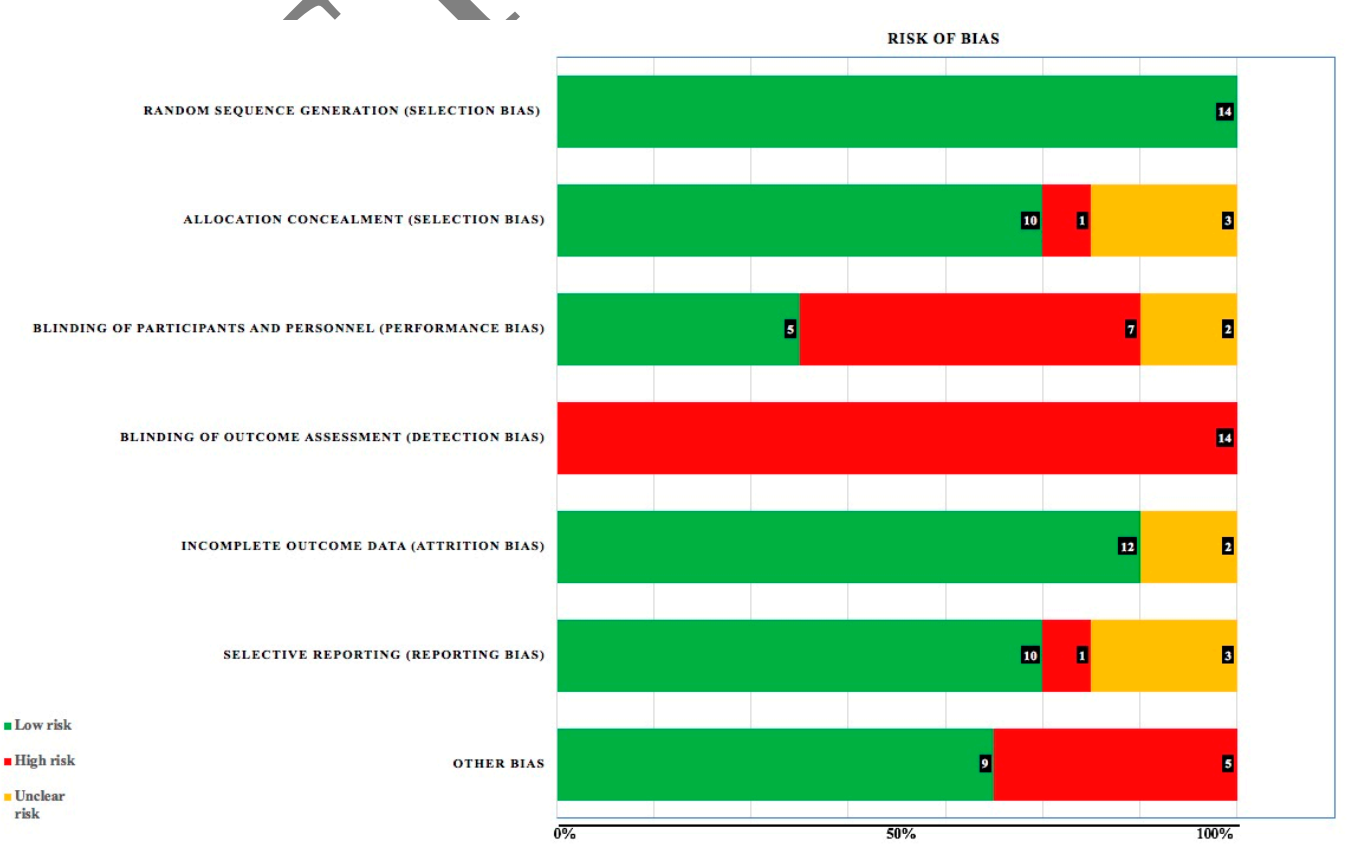

Figure 3. Risk of bias. 
The STROBE criteria reported an average score of $27.4( \pm 0.85)$, the maximum scores corresponding to the studies by Al-Halabi et al. [20] and Mitrakul et al. [27]. It is also noteworthy that Item 9 (Bias) was only reported in five studies [21,22,24,26,27], which is also the case with Item 19 (Limitations) [20-22,26,27] (Table 1).

\subsection{VR and Anxiety Management}

Regarding anxiety, the composite measure is not significant, neither for all together (children + adults) $(p=0.302)$, nor for children $(p=0.243)$ (Figure 4$)$ nor adults $(p=0.567)$ (Figure 5). The heterogeneity seems to be moderate (Table 3 ).
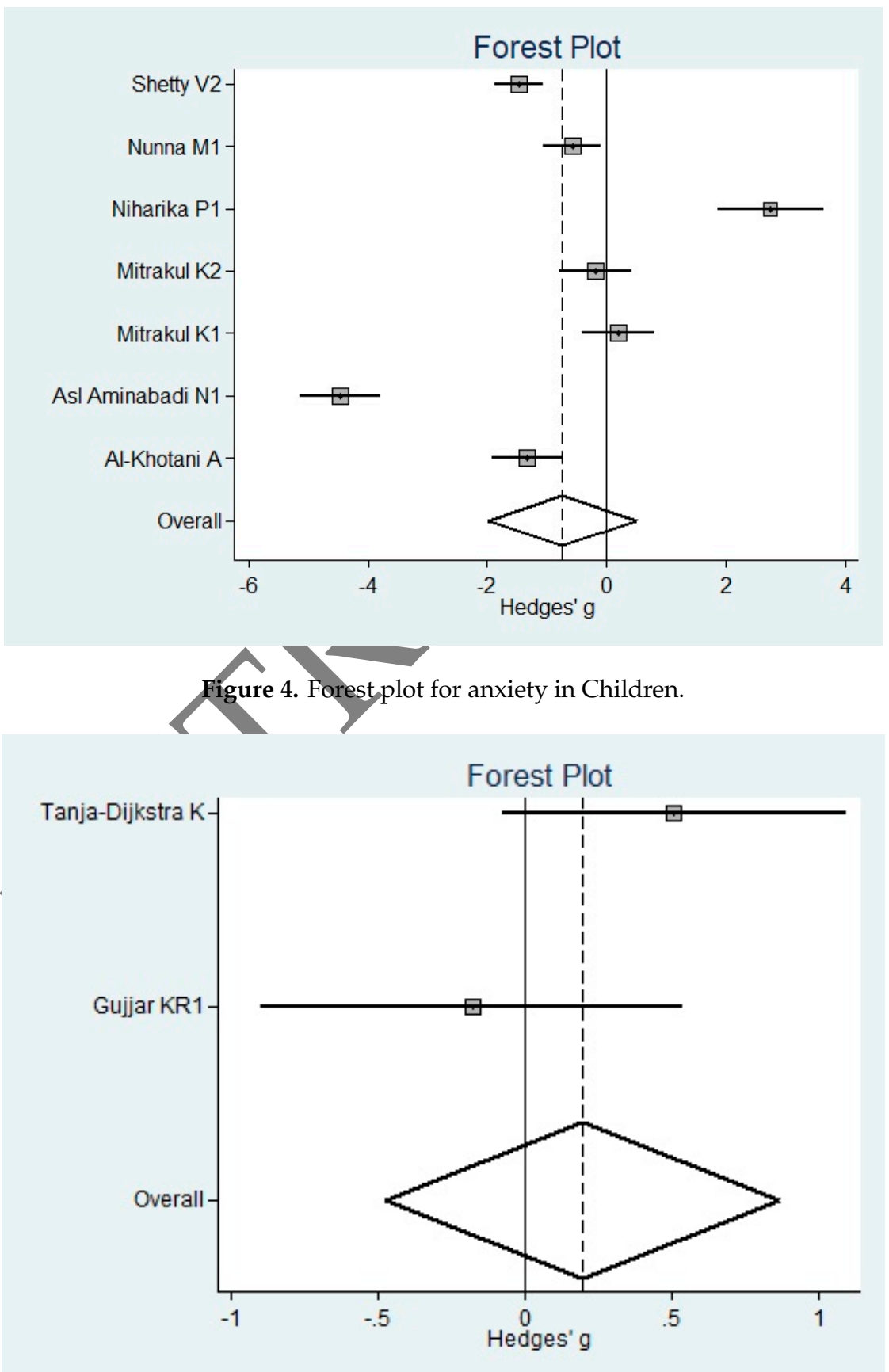

Figure 5. Forest plot for Anxiety in Adults. 
Table 3. Meta-analysis of anxiety. Characteristics of individual studies and meta-analysis. a: Standardized difference of means.

\begin{tabular}{|c|c|c|c|c|c|c|c|c|c|c|c|c|}
\hline \multirow{2}{*}{ Age group/Study } & \multirow{2}{*}{ Year } & \multirow{2}{*}{ Scale } & \multicolumn{2}{|c|}{ Test } & \multicolumn{3}{|c|}{ Control } & \multicolumn{3}{|c|}{ SMD $^{a}$} & \multirow{2}{*}{$\begin{array}{l}\text { Heterogeneity } \\
\mathrm{I}^{2}(p \text {-Value) }\end{array}$} & \multirow{2}{*}{$\begin{array}{c}\text { Public.bias } \\
p \text {-Value } \\
\text { (Egger Test }\end{array}$} \\
\hline & & & $n$ & Mean $\pm \mathrm{sd}$ & $n$ & Mean \pm sd & Weight & Mean & $95 \%$-CI & $p$-Value & & \\
\hline Children + Adults $(n=9)$ & & & 282 & & 284 & & & -0.54 & -1.58 to 0.49 & 0.302 & $31 \%(p=0.169)$ & $p=0.399$ \\
\hline \multicolumn{13}{|l|}{$\begin{array}{l}\text { Children }(n=7) \\
\text { (see Figure 5) }\end{array}$} \\
\hline Shetty V2 [25] & 2019 & MDAS & 60 & $11.3 \pm 3.5$ & 60 & $16.5 \pm 3.5$ & $14.6 \%$ & -1.48 & -1.88 to -1.07 & & & \\
\hline Nunna M1 [23] & 2019 & VCARS & 35 & $0.57 \pm 0.61$ & 35 & $1.00 \pm 0.84$ & $14.5 \%$ & -0.58 & -1.06 to -0.10 & & & \\
\hline Niharika P1 [24] & 2018 & MDAS & 20 & $19.6 \pm 0.9$ & 20 & $17.3 \pm 0.8$ & $13.8 \%$ & 2.74 & 1.86 to 3.63 & & & \\
\hline Mitrakul K2 [27] & 2015 & FLACC & 21 & $26.0 \pm 9.1$ & 21 & $28.0 \pm 12.0$ & $14.3 \%$ & -0.18 & -0.79 to 0.43 & & & \\
\hline Mitrakul K1 [27] & 2015 & FLACC & 21 & $29.5 \pm 11.3$ & 21 & $27.3 \pm 10.6$ & $14.3 \%$ & 0.20 & -0.41 to 0.80 & & & \\
\hline Asl Aminabadi N1 [22] & 2012 & MDAS & 60 & $12.6 \pm 1.0$ & 60 & $17.7 \pm 1.2$ & $14.2 \%$ & -4.46 & -5.14 to -3.78 & & & \\
\hline Al-Khotani A [26] & 2016 & MDAS & 28 & $0.14 \pm 0.36$ & 28 & $0.75 \pm 0.52$ & $14.3 \%$ & -1.34 & -1.93 to -0.76 & & & \\
\hline Total & & & 245 & & 245 & & $100 \%$ & -0.74 & -1.99 to 0.51 & 0.243 & $38 \%(p=0.139)$ & $p=0.536$ \\
\hline \multicolumn{13}{|l|}{ Adults $(n=2)$ (see Figure 6$)$} \\
\hline Tanja-Dijkstra K [9] & 2014 & MDAS & 22 & $3.73 \pm 0.65$ & 24 & $3.33 \pm 0.87$ & $54.6 \%$ & 0.51 & -0.08 to 1.10 & & & \\
\hline Gujjar KR1 [6] & 2019 & MDAS & 15 & $18.3 \pm 2.6$ & 15 & & $45.4 \%$ & -0.18 & -0.90 to 0.54 & & & \\
\hline Total & & & 37 & & 39 & & & 0.20 & -0.48 to 0.87 & 0.567 & $0 \%(p=0.317)$ & - \\
\hline
\end{tabular}




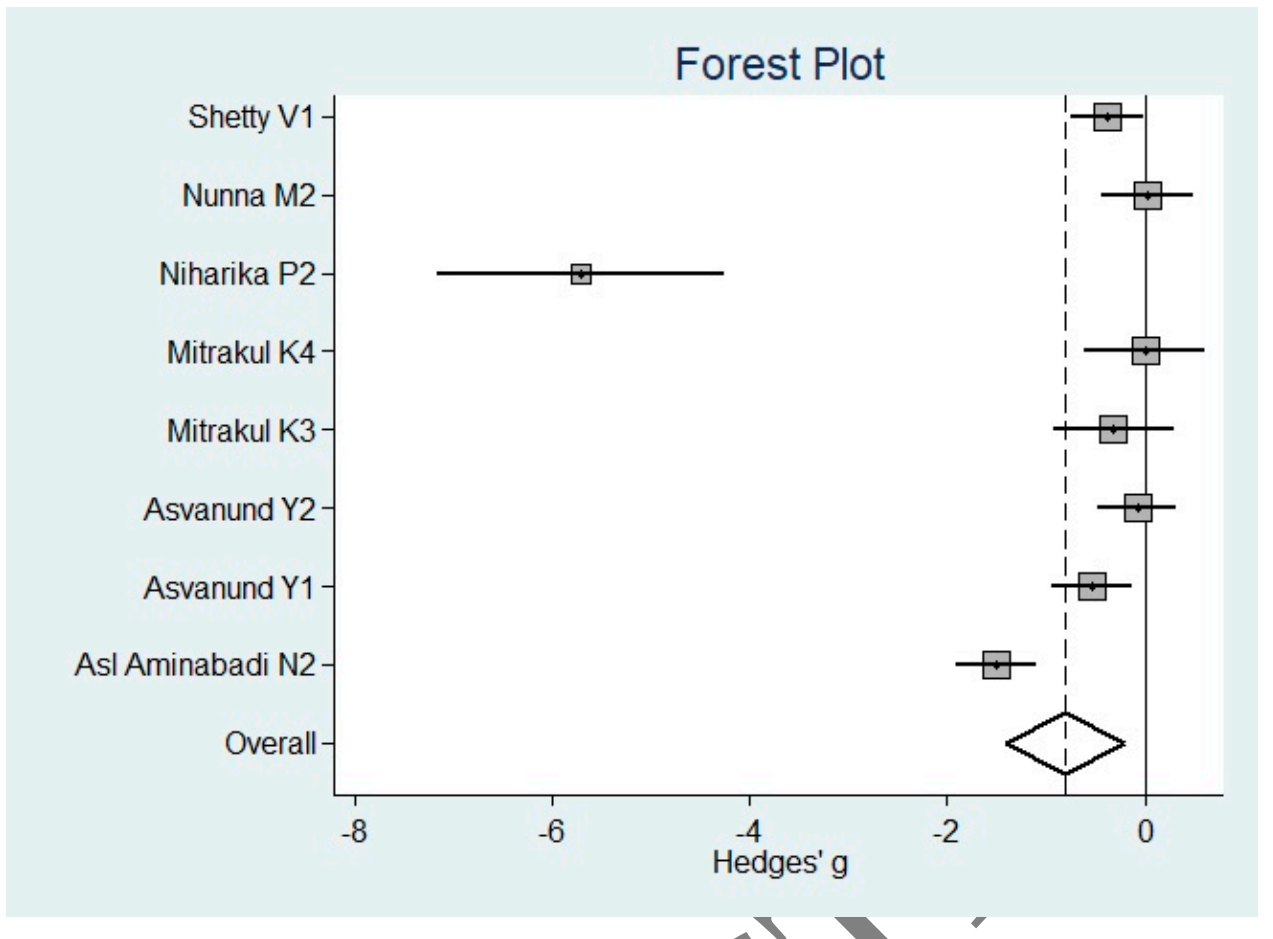

Figure 6. Forest plot for pain in Children.

\subsection{VR and Pain Management}

For pain, there is a significant protection for children (SMD $=-0.82$, i.e., a substantial effect according to Cohen's scale [29]) (Figure 6), but not for adults (Figure 7), since the 95\%-confidence interval (CI) includes the null value 0 (Table 4). Nevertherless, it is based only on two studies.
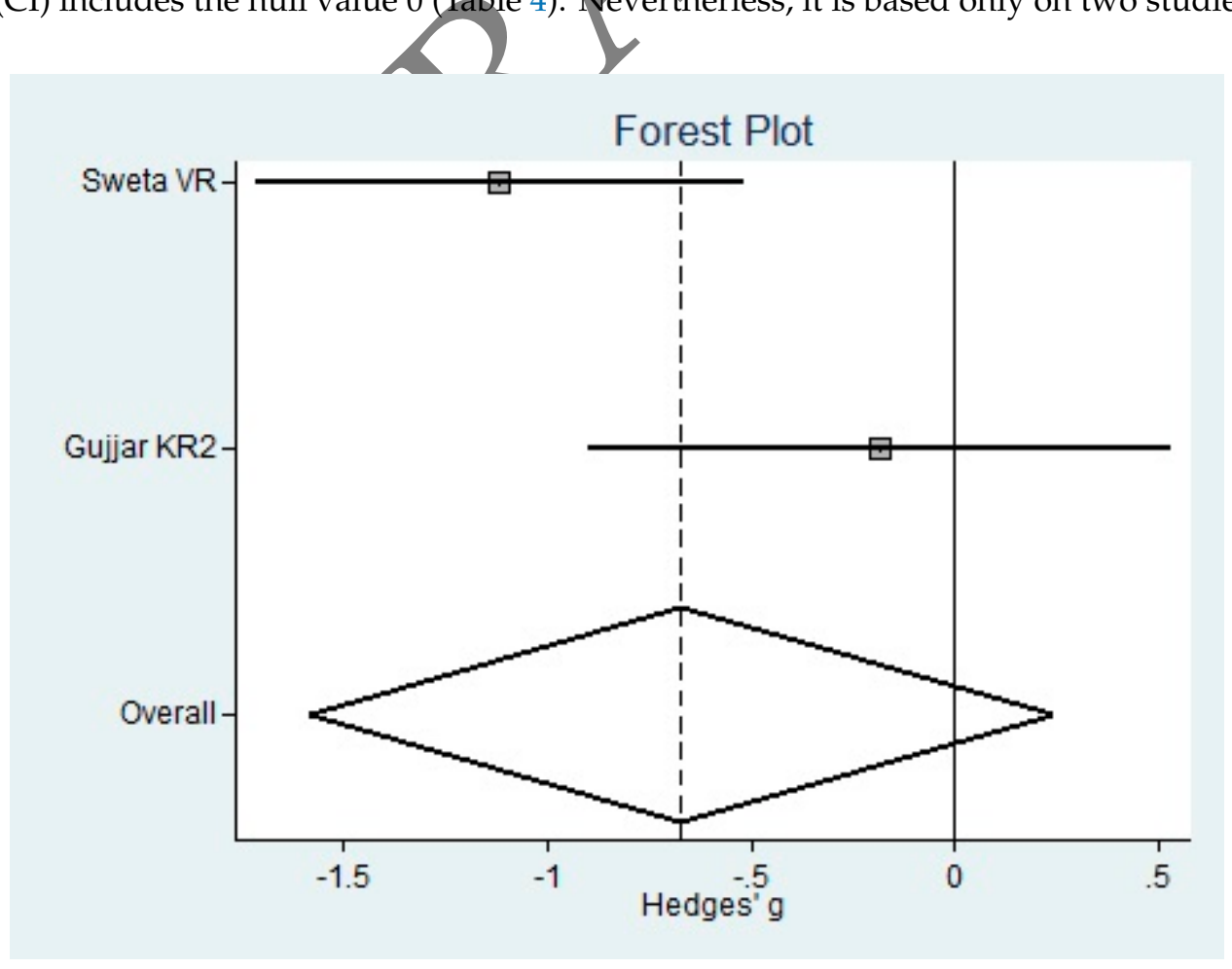

Figure 7. Forest plot for Pain in Adults. 
Table 4. Meta-analysis of pain according to random effect models. Characteristics of individual studies and meta-analysis. a: Standardized difference of means.

\begin{tabular}{|c|c|c|c|c|c|c|c|c|c|c|c|c|}
\hline \multirow{2}{*}{ Age group/Study } & \multirow{2}{*}{ Year } & \multirow{2}{*}{ Scale } & \multicolumn{2}{|c|}{ Test } & \multicolumn{3}{|c|}{ Control } & \multicolumn{3}{|c|}{$\mathrm{SMD}^{\mathrm{a}}$} & \multirow{2}{*}{$\begin{array}{c}\text { Heterogeneity } \\
\mathrm{I}^{2}(p \text {-Value) }\end{array}$} & \multirow{2}{*}{$\begin{array}{c}\text { Public.bias } \\
p \text {-Value } \\
\text { (Egger Test) }\end{array}$} \\
\hline & & & $\mathrm{n}$ & Mean \pm sd & $\mathrm{n}$ & Mean \pm sd & Weight & Mean & $95 \%-\mathrm{CI}$ & $p$-Value & & \\
\hline Children + Adults $(n=10)$ & & & 355 & & 355 & & & -0.77 & -1.28 to -0.26 & 0.003 & $65.8 \%(0.002)$ & 0.173 \\
\hline \multicolumn{13}{|l|}{$\begin{array}{l}\text { Children }(n=8) \\
\text { (see Figure } 7)\end{array}$} \\
\hline Shetty V1 [25] & 2019 & W-BFS & 60 & $2.00 \pm 0.50$ & 60 & $2.42 \pm 1.47$ & $13.6 \%$ & -0.38 & -0.74 to -0.0 & & & \\
\hline Nunna M2 [23] & 2019 & W-BFS & 35 & $3.03 \pm 2.22$ & 35 & $2.97 \pm 2.49$ & $13.2 \%$ & 0.03 & -0.44 to 0.49 & & & \\
\hline Niharika P2 [24] & 2018 & W-BFS & 20 & $2.56 \pm 0.39$ & 20 & $5.22 \pm 0.51$ & $7.8 \%$ & -5.71 & -7.16 to -4.25 & & & \\
\hline Mitrakul K4 [27] & 2015 & FPS-R & 21 & $1.90 \pm 2.93$ & 21 & $1.90 \pm 3.32$ & $12.5 \%$ & 0.00 & -0.60 to 0.60 & & & \\
\hline Mitrakul K3 [27] & 2015 & FPS-R & 21 & $0.86 \pm 1.49$ & 21 & $1.62 \pm 2.94$ & $12.5 \%$ & -0.32 & -0.93 to 0.29 & & & \\
\hline Asvanund Y2 [28] & 2015 & FPS-R & 49 & $2.23 \pm 2.29$ & 49 & $2.46 \pm 3.46$ & $13.5 \%$ & -0.08 & -0.47 to 0.32 & & & \\
\hline Asvanund Y1 [28] & 2015 & FPS-R & 49 & $1.57 \pm 2.29$ & 49 & $3.04 \pm 3.08$ & $13.5 \%$ & -0.54 & -0.94 to -0.13 & & & \\
\hline Asl Aminabadi N2 [22] & 2012 & W-BFS & 60 & $1.89 \pm 0.65$ & 60 & $3.00 \pm 0.81$ & $13.4 \%$ & -1.50 & -1.91 to -1.10 & & & \\
\hline Total & & & 315 & & 315 & & $100 \%$ & -0.82 & -1.42 to -0.22 & 0.008 & $71 \%(p=0.001)$ & $p=0.180$ \\
\hline \multicolumn{13}{|l|}{ Adults $(n=2)$ (see Figure 7) } \\
\hline Sweta VR [2] & 2019 & VAS & 25 & $1.28 \pm 0.89$ & 25 & $2.60 \pm 1.38$ & $52.3 \%$ & -1.12 & -1.72 to -0.52 & & & \\
\hline Gujjar KR2 [6] & 2019 & VAS & 15 & $68 \pm 10$ & 15 & & $47.7 \%$ & -0.18 & -0.90 to 0.53 & & & \\
\hline Total & & & 40 & & 40 & & & -0.67 & -1.58 to 0.24 & 0.149 & $0 \%(p=0.317)$ & - \\
\hline
\end{tabular}




\subsection{Publication Bias and Heterogeneity}

All estimates seem not to be affected by publication bias, according to the Egger test (Tables 1 and 2), but heterogeneity seems to be substantial.

\section{Discussion}

While anxiety and pain are usually associated with dental treatments, the number of studies addressing their management, especially during anesthetic block, which is one of the procedures that usually causes great anxiety among patients, is very limited [2,30].

Although most studies are based on pediatric population, fear of dental treatment affects $15 \%-20 \%$ of the population, being recognized by the World Health Organization (WHO) as a real pathology $[3,31,32]$ that leads those who are affected by it to reject even the most basic dental treatments, such as simple dental check-ups or cleanings [33]; thus, its management is essential to improve the patient's quality of life [34].

Despite the existence of rigorous reviews of literature [5], we believe that this is the first systematic review and meta-analysis focused on the efficacy of VR in patients, regardless of age, who suffer from anxiety triggered by dental treatments.

Our meta-analysis is based on 10 studies: two on pain, two on DA and six on DA and P together, and has proved that VR is an effective tool for reducing pain $(S M D=-0.82)$, as reported by child patients during a variety of dental procedures.

Some studies proved that, both for pain and anxiety, the use of VR was more effective in children than in adults. A possible reason for this could be that VR is especially appealing to children, since they become more engaged in whimsical thinking and are fascinated by imaginative play [35].

Nevertheless, regarding age, it should be noted that the differences in the efficacy of VR, in each study, could be due to the interpretive problems to which these analyses are susceptible; such phenomenon, known as ecological fallacies, could be associated either to the heterogeneity of the study's characteristics (methodologicaldiversity), or to the study populations (clinical diversity) [36].

VR was found to be more effective for treating P and DA than conventional treatments; however, it is difficult to assess its efficacy as compared to other types of distraction. Klassen and colleagues [37] conducted a meta-analysis on distraction using music therapy as an alternative method to reduce anxiety and pain in different medical and dental procedures, finding a significant reduction, with an effect size of 0.35 . A Cochrane review of psychological interventions using different types of distraction to relieve pain in children and adolescents, published in 2006 and updated in 2013 and 2018 [38-40], reported different distraction techniques such as musical therapy, reading, watching films, hypnosis, breathing techniques and combined cognitive-behavioral strategies, as effective tools to reduce pain and anxiety during needle procedures. However, the reviewers considered the level of certainty of the review to be low, since in most of these studies there was no blinding of participants and assessors. This is consistent with our meta-analysis, according to which only $35 \%$ of the studies included met this requirement.

The heterogeneity of VR software and hardware is also relevant to the immersive approach, which is influenced by the interaction with the virtual environment, either through translation or change of position, rotation or change of direction, viewpoint or perspective and visual field. This aspect is difficult to analyze when referred to patients who are undergoing dental treatment (especially in children), since adequate patient immersion is hindered by the fact that they are expected to remain with their heads as still as possible to facilitate the professional's work [41].

Large devices (hardware), also hinder the dentist's work, limiting vision of and access to the dental operation area [42].

Another interesting aspect that has not been given due regard by researchers is gender difference and its significance in terms of fear of dental treatment. Patients who suffer from dental phobia are characterized by a gender-specific brain structure. Such differences have not been sufficiently addressed 
by researchers and clinicians, and could contribute to greater effectiveness in the management of dental phobia [43].

Likewise, patients' different personality traits were not considered in the studies included, either. Patients with dental fear and a high predisposition to anxiety magnify their pain expectations when they are exposed to critical situations. When patients with dental anxiety undergo dental treatment, their beliefs about the negative consequences of bodily excitement can negatively influence their assessment of pain linked to such treatment [44]. DA as a predisposing factor is associated with a state of anxiety, which has a constant impact on pain during the patient's entire dental treatment; hence, anxiety should be assessed as a critical step not only towards anxiety management in patients with high DA, but also towards P management in all dental patients [45].

On the other hand, the studies included used different pain and DA assessment scales: VAS, W-BFS, FPS-R FLACC, VRS, MDAS, NCAQ and VCARS. Likewise, none of the studies included single scales for joint assessment by dentist and patient. Vital signs as emotional state indicators were also assessed in some of the studies, thus it would be convenient and appropriate to find validated scales that might be used to adequately assess all of these aspects [46].

Eijlers and colleagues [5,47] presented two preparatory studies for pediatric surgery based on VR training programs; however, the use of this type of preparatory program before certain dental procedures is yet to be explored by researchers and, therefore, it is currently not possible to compare effects with and without preparation.

Moreover, none of the studies drew attention to factors that could moderate VR's effectiveness, such as a subject's sensitivity to anxiety or their temperament. Shy and emotional temperaments could be associated with dental anxiety [48-51].

For all these reasons, we believe that this systematic reylew has certain limitations in terms of number, quality and methodology of the studies included: only three studies in adults were included $[2,6,9]$, which is too scarce to consider them significant in our analysis, the authors themselves even acknowledge the limited sample size in one of them [2], and the existence of major limitations with regard to participant and assessor blinding, inanother [6].

Hence, to determine the effects of VR on anxiety and pain in dental treatments, it would be necessary to reduce the risk of bias, to remove confusion factors and to establish a clear definition of the adequate parameters, all with the purpose of obtaining results that can be translated into broad clinical applications, so that the evidenee can effectively support the practice of clinical dentistry.

\section{Conclusions}

This systematic review and meta-analysis leads to the conclusion that VR is a useful tool to reduce $P$ in children undergoing dental treatment. No significant effect was found for DA. Studies in adults are scarce. On the other hand, most of the studies chose to focus on immersion in the pediatric population, neglecting a series of aspects that should be considered, such as training programs, the different types of software and hardware of virtual reality devices, the temperament and patient personality, gender difference and more. Due to all this, the role of virtual reality in the control of anxiety and dental pain in children and adults should be considered as a topic for future research.

Author Contributions: Study concept and design: N.L.-V., A.L.-V., J.M.F.; Acquisition of data (Literature search and Study Selection): N.L.-V., J.F.F., J.M.R.; Analysis and interpretation of data (literature): M.B., L.F.V.J., J.H.P., L.A.B.A.; Drafting of the manuscript: N.L.-V.; A.L.-V., B.M.d.S.; Critical revision of the manuscript for important intellectual content: A.L.-V., M.B. All authors have read and agreed to the published version of the manuscript.

Conflicts of Interest: The authors declare no conflict of interest. 


\section{Abbreviations}

VR
DA
VAS
W-BFS
FPS-R
FLACC
VRS
MDAS
NCAQ
VCARS
RoB
SDs
SMD
CI

\section{References}

1. López-Valverde, A.; Montero, J.; Albaladejo, A.; Gómez de Diego, R. The discovery of surgical anesthesia: Discrepancies regarding its authorship. J. Dent. Res. 2011, 90, 31-34. [Crossef] [PubMed]

2. Sweta, V.R.; Abhinav, R.P.; Asha, R. Role of Virtual Reality in Pain Perception of Patients Following the Administration of Local Anesthesia. Ann. Maxillofac. Surg. 2019, 9, 110-113. [PubMed]

3. Ougradar, A.; Ahmed, B. Patients' perceptions of the benefits of virtual reality during dental extractions. Br. Dent. J. 2019, 227, 813-816. [CrossRef] [PubMed]

4. Carl, E.; Stein, A.T.; Levihn-Coon, A.; Pogue, J.R.; Rothbaum, B.; Emmelkamp, P.; Asmundson, G.; Carlbring, P.; Powers, M.B. Virtual reality exposure therapy for anxiety and related disorders: A meta-analysis of randomized controlled trials. J. Anxiety Disord. 2019, 61, 27-36. [CrossRef]

5. Eijlers, R.; Utens, E.; Staals, L.M.; de Nijs, P.F.A.; Berghmans, J.M.; Wijnen, R.M.H.; Hillegers, M.H.J.; Dierckx, B.; Legerstee, J.S. Systematic Reyiew and Meta-analysis of Virtual Reality in Pediatrics: Effects on Pain and Anxiety. Anesth. Analg. 2019, 129, 1344-1353. [CrossRef]

6. Gujjar, K.R.; van Wijk, A.; Kumar, R.; de Jongh, A. Efficacy of virtual reality exposure therapy for the treatment of dental phobia in adults: A randomized controlled trial. J. Anxiety Disord. 2019, 62, 100-108. [CrossRef]

7. Raghav, K.; Van Wijk, A.J.; Abdullah, F.; Islam, M.N.; Bernatchez, M.; De Jongh, A. Efficacy of virtual reality exposure therapy for treatment of dental phobia: A randomized control trial. BMC Oral Health 2016, $27,25$. [CrossRef]

8. Wiederhold, M.D. Gao, K. Wiederhold, B.K. Clinical use of virtual reality distraction system to reduce anxiety and pain in dental procedures. Cyberpsychol. Behav. Soc. Netw. 2014, 17, 359-365. [CrossRef]

9. Tanja-Dijkstra, K.; Pahl, S.; White, M.P.; Andrade, J.; Qian, C.; Bruce, M.; May, J.; Moles, D.R. Improving dental experiences by using virtual reality distraction: A simulation study. PLoS ONE 2014, 2, e91276. [CrossRef]

10. Dahlquist, L.M.; McKenna, K.D.; Jones, K.K.; Dillinger, L.; Weiss, K.E.; Ackerman, C.S. Active and passive distraction using a head-mounted display helmet: Effects on cold pressor pain in children. Health Psychol. 2014, 26, 794-801. [CrossRef]

11. Schneider, S.M.; Hood, L.E. Virtual reality: A distraction intervention for chemotherapy. Oncol. Nurs. Forum 2007, 34, 39-46. [CrossRef] [PubMed]

12. Malloy, K.M.; Milling, L.S. The effectiveness of virtual reality distraction for pain reduction: A systematic review. Clin. Psychol. Rev. 2010, 30, 1011-1018. [CrossRef] [PubMed]

13. American Society of Anesthesiologists Task Force on Sedation and Analgesia by Non-Anesthesiologists. Practice guidelines for sedation and analgesia by non-anesthesiologists. Anesthesiology 2002, 96, 1004-1017. [CrossRef] [PubMed]

14. Dixon, R.A.; Kenyon, C.; Marsh, D.R.; Thornton, J.A. Midazolam in conservative dentistry. A cross-over trial. Anaesthesia 1986, 41, 276-281. [CrossRef]

15. Foley, J. The way forward for dental sedation and primary cares? Br. Dent. J. 2002, 193, 161-164. [CrossRef] 
16. Hutton, B.; Ferrán Catalá-López, F.; Moher, D. The PRISMA statement extension for systematic reviews incorporating network meta-analysis: PRISMA-NMA. Med. Clin. 2016, 16, 262-266. [CrossRef]

17. Higgins, J.P.T.; Altman, D.G.; Sterne, J.A.C. Cochrane Handbook for Systematic Reviews of Interventions, version 5.1.0; Higgins, J.P.T., Green, S., Eds.; The Cochrane Collaboration: London, UK, 2006; Chapter 8; Available online: http://www.cochrane-handbook.org (accessed on 20 October 2019).

18. Vandenbroucke, J.P.; von Elm, E.; Altman, D.G.; Gøtzsche, P.C.; Mulrow, C.D.; Pocock, S.J.; Charles, P.; James, J.S.; Matthias, E. STROBE Initiative. Strengthening the reporting of observational studies in epidemiology (STROBE): Explanation and elaboration. PLoS Med. 2007, 4, e297. [CrossRef]

19. Tanja-Dijkstra, K.; Pahl, S.; White, M.P.; Andrade, J.; May, J.; Stone, R.J.; Bruce, M.; Mills, I.; Auvray, M.; Gabe, R.; et al. Can virtual nature improve patient experiences and memories of dental treatment? A study protocol for a randomized controlled trial. Trials 2014, 22, 90. [CrossRef]

20. Al-Halabi, M.N.; Bshara, N.; AlNerabieah, Z. Effectiveness of audio visual distraction using virtual reality eyeglasses versus tablet device in child behavioral management during inferior alveolar nerve block. Anaesth. Pain Intensive Care 2018, 22, 55-61.

21. Bentsen, B.; Svensson, P.; Wenzel, A. Evaluation of effect of 3D video glasses on perceived pain and unpleasantness induced by restorative dental treatment. Eur. J. Pain 2001, 5,373-378. [CrossRef]

22. Asl Aminabadi, N.; Erfanparast, L.; Sohrabi, A.; Ghertasi Oskouei, S.; Naghili, A. The Impact of Virtual Reality Distraction on Pain and Anxiety during Dental Treatment in 4-6 Year-Old Children: A Randomized Controlled Clinical Trial. J. Dent. Res. Dent. Clin. Dent. Prospect. 2012, 6, 117-124.

23. Nunna, M.; Dasaraju, R.K.; Kamatham, R.; Mallineni, S.K.; Nuvvula, S. Comparative evaluation of virtual reality distraction and counter-stimulation on dental anxiety and pain perception in children. J. Dent. Anesth. Pain Med. 2019, 19, 277-288. [CrossRef] [PubMed]

24. Niharika, P.; Reddy, N.V.; Srujana, P.; Srikanth, K.; Daneswari, V.; Geetha, K.S. Effects of distraction using virtual reality technology on pain perception and anxiety levels in/children during pulp therapy of primary molars. J. Indian Soc. Pedod. Prev. Dent. 2018, 36, 364-369. [CrossRef] [PubMed]

25. Shetty, V.; Suresh, L.R.; Hegde, A.M. Effect of Virtual Reality Distraction on Pain and Anxiety during Dental Treatment in 5 to 8 Year Old Children. J. Clin. Pediatr. Dent. 2019, 43, 97-102. [CrossRef]

26. Al-Khotani, A.; Bello, L.A.; Christidis, N. Effects of audiovisual distraction on children's behaviour during dental treatment: A randomized controlled clinical trial. Acta Odontol. Scand. 2016, 74, 494-501. [CrossRef] [PubMed]

27. Mitrakul, K.; Asvanund, Y Arunakul, M.; Paka-Akekaphat, S. Effect of audiovisual eyeglasses during dental treatment in 5-8 year-old children. Eur. J. Paediatr. Dent. 2015, 16, 239-245. [PubMed]

28. Asvanund, Y.; Mitrakul, K.; Juhong, R.O.; Arunakul, M. Effect of audiovisual eyeglasses during local anesthesia injections in 5- to 8-year-old children. Quintessence Int. 2015, 46, 513-521.

29. Cohen, J. Statistical Power Analysis for the Behavioral Sciences, 2nd ed.; Lawrence Erlbaum Associates: New York, NY, USA, 1988.

30. Yamashita, Y.; Shimohira, D.; Aijima, R.; Mori, K.; Danjo, A. Clinical Effect of Virtual Reality to Relieve Anxiety During Impacted Mandibular Third Molar Extraction Under Local Anesthesia. J. Oral Maxillofac. Surg. 2019, 26, 31343-31346. [CrossRef]

31. Hill, K.B.; Chadwick, B.; Freeman, R.; O'Sullivan, I.; Murray, J.J. Adult Dental Health Survey 2009: Relationships between dental attendance patterns, oral health behaviour and the current barriers to dental care. Br. Dent. J. 2013, 214, 25-32. [CrossRef]

32. Seligman, L.D.; Hovey, J.D.; Chacon, K.; Ollendick, T.H. Dental anxiety: An understudied problem in youth. Clin. Psychol. Rev. 2017, 55, 25-40. [CrossRef]

33. De Stefano, R. Psychological Factors in Dental Patient Care: Odontophobia. Medicina 2019, 8, 55. [CrossRef] [PubMed]

34. Fiorillo, L. Oral Health: The First Step to Well-Being. Medicina 2019, 7, 55. [CrossRef] [PubMed]

35. Bolton, D.; Dearsley, P.; Madronal-Luque, R.; Baron-Cohen, S. Magical thinking in childhood and adolescence: Development and relation to obsessive compulsion. Br. J. Dev. Psychol. 2002, 20, 479-494. [CrossRef]

36. Thompson, S.G.; Higgins, J.P. How should meta-regression analyses be undertaken and interpreted? Stat. Med. 2002, 21, 559-573. [CrossRef] 
37. Klassen, J.A.; Liang, Y.; Tjosvold, L.; Klassen, T.P.; Hartling, L. Music for pain and anxiety in children undergoing medical procedures: A systematic review of randomized controlled trials. Ambul. Pediatr. 2008, 8, 117-128. [CrossRef]

38. Uman, L.S.; Chambers, C.T.; McGrath, P.J.; Kisely, S. Psychological interventions for needle-related procedural pain and distress in children and adolescents. Cochrane Database Syst. Rev. 2006, 18. [CrossRef]

39. Uman, S.L.; Birnie, K.A.; Noel, M.; Parker, J.A.; Chambers, C.T.; McGrath, P.J.; Kisely, S.R. Psychological interventions for needle-related procedural pain and distress in children and adolescents. Cochrane Database Syst. Rev. 2013, 10. [CrossRef]

40. Birnie, K.A.; Noel, M.; Chambers, C.T.; Uman, L.S.; Parker, J.A. Psychological interventions for needle-related procedural pain and distress in children and adolescents. Cochrane Database Syst. Rev. 2018, 10. [CrossRef]

41. Hoffman, H.G.; Sharar, S.R.; Coda, B.; Everett, J.J.; Ciol, M.; Richards, T.; Patterson, D.R. Manipulating presence influences the magnitude of virtual reality analgesia. Pain 2004, 111, 162-168. [CrossRef]

42. Yu, M.; Zhou, R.; Wang, H.; Zhao, W. An evaluation for VR glasses system user experience: The influence factors of interactive operation and motion sickness. Appl. Ergon. 2019, 74, 206-213. [CrossRef]

43. Schienle, A.; Scharmüller, W.; Leutgeb, V.; Schäfer, A.; Stark, R. Sex differences in the functional and structural neuroanatomy of dental phobia. Brain Struct. Funct. 2013, 218, 779-787. [Cp ssRef]

44. Klages, U.; Kianifard, S.; Ulusoy, O.; Wehrbein, H. Anxiety sensitivity as predictor of pain in patients undergoing restorative dentalprocedures. Community Dent. Oral Epidemiol, 2006, 34, 139-145. [CrossRef] [PubMed]

45. Lin, C.S.; Wu, S.Y.; Yi, C.A. Association between Anxiety and Pain in Dental Treatment: A Systematic Review and Meta-analysis. J. Dent. Res. 2017, 96, 153-162. [CrossRe1] [PutrMed]

46. Astramskaite, I.; Juodžbalys, G. Scales used to rate adult patients' psycho-emotional status in tooth extraction procedures: A systematic review. Int. J. Oral Maxillofac. Surg. 2017, 46, 886-898. [CrossRef] [PubMed]

47. Eijlers, R.; Legerstee, J.S.; Dierckx, B.; Staals, L.M.; Berghmans, J.; van der Schroeff, M.P.; Wijnen, R.M.; Utens, E.M. Development of a Virtual Reality Exposure Tool as Psychological Preparation for Elective Pediatric Day Care Surgery: Methodological Approach for a Randomized Controlled Trial. JMIR Res. Protoc. 2017, 6, e174. [CrossRef] [PubMed]

48. Jain, A.; Suprabha, B.S.; Shenoy, R.; Rao, A. Association of temperament with dental anxiety and behaviour of the preschool child during the initial dental visit. Eur. J. Oral Sci. 2019, 127, 147-155. [CrossRef] [PubMed]

49. Stenebrand, A.; Wide Boman, U.; Hakeberg, M. Dental anxiety and temperament in 15-year olds. Acta Odontol. Scand. 2013, 71, 15-21. [CrossRet]

50. Lundgren, J.; Elfström, M.L.; Berggren, U. The relationship between temperament and fearfulness in adult dental phobic patients. Int. J. Paediatr. Dent. 2007, 17, 460-468. [CrossRef]

51. Bergdahl, M.; Bergdahl, J Temperament and character personality dimensions in patients with dental anxiety. Eur. J. Oral. Sei. 2003, 111, 93-98. [CrossRef]

C 2020 by the authors. Licensee MDPI, Basel, Switzerland. This article is an open access article distributed under the terms and conditions of the Creative Commons Attribution (CC BY) license (http://creativecommons.org/licenses/by/4.0/). 